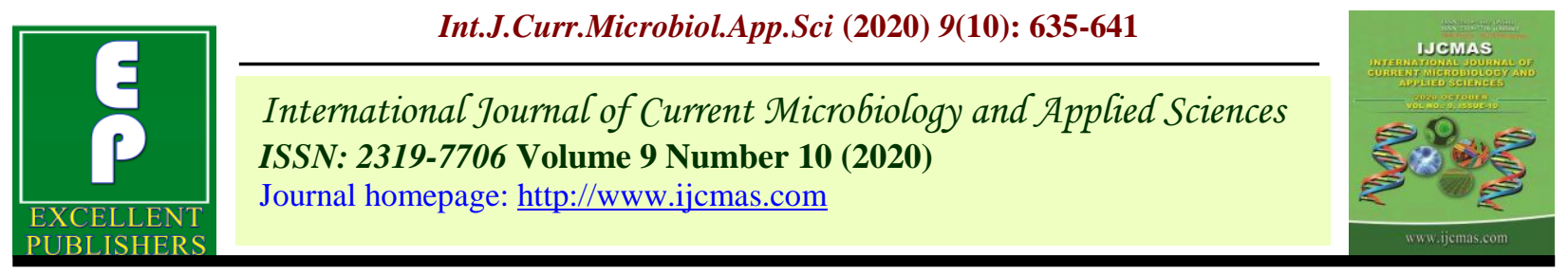

Original Research Article

https://doi.org/10.20546/ijcmas.2020.910.075

\title{
Seed Quality Improvement in Amaranthus polygonoides var. PLR 1 through Specific Gravity Separator
}

\author{
R. Kavinila*, R. Geetha, R. Chandraprakash and K. Sujatha \\ Department of Seed Science and Technology, Agricultural College and Research Institute \\ Tamil Nadu Agricultural University, Madurai- 625104, India \\ *Corresponding author
}

\begin{tabular}{l} 
Ke y w o r d s \\
$\begin{array}{l}\text { Amaranthus } \\
\text { polygonoides, } \\
\text { Specific gravity, } \\
\text { Vigour }\end{array}$ \\
Article Info \\
$\begin{array}{l}\text { Accepted: } \\
\text { 07 September } 2020 \\
\text { Available Online: } \\
10 \text { October } 2020\end{array}$ \\
\hline
\end{tabular}

Keywords

Amaranthus polygonoides, Specific gravity, Vigour

Article Info

Accepted:

10 October 2020

\author{
A B S T R A C T
}

\begin{abstract}
An experiment was conducted toget vigorous seedlings through processing in Amaranthus polygonoides var. PLR 1 seeds. The seeds of Amaranthus polygonoides var. PLR 1 were subjected to specific gravity separation at different combinations of machine settings like vertical height $(0.5,1,1.5)$, horizontal height $(0.5,1,1.5 \mathrm{~cm})$, air flow rate $\left(3,3.5 \mathrm{~m}^{3} / \mathrm{hr}\right)$ and deck oscillation speed $(400,450,465$ $\mathrm{rpm})$. The seeds were separated into five grades from heaviest, heavy, medium, light, lightest weighed seeds as grade A, B, C, D, E respectively. The E grade represents the low weighed seeds and $\mathrm{A}$ grade represents the heavy weighed seeds. After grading the seeds are tested for its seed quality parameters like seed germination, shoot length, root length, dry matter, vigour index, 1000 seed weight, seed recovery percentage. The results revealed that the machine setting with 0.5 $\mathrm{cm}$ of vertical height, $1.5 \mathrm{~cm}$ of horizontal height, $3.5 \mathrm{~m}^{3} / \mathrm{hr}$ of air flow rate, and $465 \mathrm{rpm}$ of deck oscillation speed recorded recovery percentage of $92 \%$ (grade A + grade B) with the highest 1000 seed weight and $83 \%$ of germination and vigour index of 701 .
\end{abstract}

\section{Introduction}

Amaranthus is the leafy vegetable belongs to the family Amaranthaceae. Amaranthus is also known as Poor man's Spinach because of its high nutrition at cheaper cost. It is the rich source of protein. Among the twenty five species of Amaranthus, Amaranthus polygonoides var. PLR 1 have nutrients like iron (38.5 mg/ $100 \mathrm{~g}$ of leaves), calcium, vitamin $A$ and vitamin $C$. with a crop duration of 65- 70 days. It is highly nutritive, adapts to various climatic conditions and propagated through seeds. Seeds produced are heterogeneous due to floral biology necessitates seed upgrading. Specific gravity separator is the grading technique based on the seed weight and density. Yogeesha et al., (2013) reported that specific gravity separator was efficient in grading and improves the quality of okra seeds thereby improved the field emergence percentage. Chandraprakash et al., (2019) reported that the oil and protein content decreases when the weight of the seed 
decreases in caster. Late formed spikes of Amaranthus polygonoides var. PLR 1produces many ill filled and immature seeds, poses the problem of seed processing with seed grader. Hence an attempt was done with specific gravity separator with different machine settings to upgrade the seeds of Amaranthus polygonoides var. PLR 1.

\section{Materials and Methods}

The experiment was conducted at Department of seed Science and Technology, Agricultural college and Research Institute, Madurai. Fresh seeds of Amaranthus polygonoides var. PLR 1 were graded in specific gravity separator based on their density. It works on the principle of specific gravity. The seeds were graded with different machine settings like vertical slope $(0.5,1,1.5 \mathrm{~cm})$, horizontal slope $(0.5,1,1.5 \mathrm{~cm})$, air blow rate $(3,3.5$ $\mathrm{m}^{3} / \mathrm{hr}$ ) and deck oscillation rate $(450,465$, $500 \mathrm{rpm}$ ). The details of treatments imposed were as follows in Table 1.

The seeds were separated into five grades from heaviest, heavy, medium, light, lightest weighed seeds as grade A,B,C,D,E respectively. Seed recovery percentage is calculated for each grade separately. The seeds with recovery percent of more than 80 (Grade A \& Grade B) were evaluated for its seed quality parameters which comes to seven combinations among the 17 combinations tested. Ungraded seeds served as control. The seed quality parameters germination (\%), shoot length $(\mathrm{cm})$, root length $(\mathrm{cm})$, dry matter(mg/10 seedlings), vigour index $\mathrm{I}$, vigour index II, and 1000 seed weight (mg) were observed. The germination test was conducted as per the ISTA (1999) rules at the room temperature of $25 \pm 1^{\circ} \mathrm{C}, \mathrm{RH}$ of $97 \pm 2^{\circ}$ $\mathrm{C}$ in the presence of white light and evaluated at the end of 14 days. Vigour index values were calculated as per Abdul-baki and Anderson (1973)
Vigour index $\mathrm{I}=$ Germination $(\%) \mathrm{x}$ Total Seedling length $(\mathrm{cm})$

Vigour index II = Germination (\%) $\mathrm{x}$ Dry matter production ( $\mathrm{g} / 10$ seedlings)

The experiment was conducted with Completely Randomized Design (CRD). The results were subjected to analysis of variance and tested (t- tested)as suggested by Panse and Sukhatme (1999) for its significant difference $(\mathrm{p}=0.05)$. Percentage values were transformed to sine values prior to statistical analysis.

\section{Results and Discussion}

In this experiment the seeds of Amaranthus polygonoides var PLR 1 were graded in specific gravity separator with different combinations of machine settings. Here the seeds after the discharge from the hopper move based upon the combination of shaking (deck oscillation speed) and air flow and collected as different grades like A,B,C,D and E. The heavy weight seeds were collected as grade A whereas light weight seeds as E. From the graded seeds, seed recovery percent and 1000 seed weight for each combination were calculated (Table 2). The maximum seed recovery percent $(98.5 \%)$ was obtained from the combination of deck slope with vertical axis as $1.0 \&$ horizontal axis as 1.5 along with the oscillation speed of 450 and air blow rate of 3 (T13) followed T4 (94.9\%) and minimum seed recovery was obtained from T2 $(10.64 \%)$.

The maximum 1000 seed weight of $77 \mathrm{mg}$ and $76 \mathrm{mg}$ with the A \& B grade seed was obtained from $\mathrm{T}_{16}(\mathrm{~V}-1.5, \mathrm{H}-1.5, \mathrm{~A}-3$, D450) followed by $\mathrm{T}_{15}(\mathrm{~V}-1.5, \mathrm{H}-1, \mathrm{~A}-3$, D450) and ungraded bulk had registered a 1000 seed weight of $65 \mathrm{mg} .1000$ seed weight of seeds revealed that there was a positive correlation between seed weight and its 
separation. The highest seed weight in T16 was due to the larger seed size and food reserves in the seed. Patil and Sarode (1988) observed that the seed weight was higher and heavy seeds compared to the light and lighter seeds for the heaviest graded seeds in Agricultural crops. Manikandan and Srimathi (2014) recorded that the 1000 seed weight was higher in heaviest fraction of seed collected.

Evaluation of seed quality parameters was done for the seeds obtained from seven machine settings (T1, T4, T5, T6, T7, T9 \& T13) which have recorded the seed recovery percentage of more than 80 percent when seeds were combined from A \& B grades. The maximum germination (83\%) was obtained from the combination $\mathrm{T}_{4}(\mathrm{~V}-0.5, \mathrm{H}-1.5, \mathrm{~A}-$ $3, \mathrm{D}-450 \mathrm{rpm})$ and followed by $\mathrm{T} 6(\mathrm{~V}-0.5$, H- 1.5, A- 3, D- 500) of $80 \%$. The minimum germination (72\%) was obtained from the combination $\mathrm{T}_{7}(\mathrm{~V}-0.5, \mathrm{H}-1, \mathrm{~A}-3.5$, D465) and $\mathrm{T}_{9}(\mathrm{~V}-0.5, \mathrm{H}-1, \mathrm{~A}-3.5, \mathrm{D}-465)$ and the ungraded seeds recorded $72 \%$ germination. Whereas the bulk recorded the germination of $72 \%$. The seeds with larger seed weight recorded the highest germination is because of large seeds have more and faster breaks in embryonic axis with the increased activity of redox enzyme that breaks the larger complex reserve food materials into simpler soluble sugars and also in other seed parts than the small seeds which results the lowest germination (Nagi et al., 1998.). The germination was higher in heavier seeds was due to well developed embryo and good seed filling and the large weight seeds have more food reserves that produces the large energy which are expressed in seedling length and seed vigour (MC Daniel., 1969).

Table.1

\begin{tabular}{|c|c|c|c|c|}
\hline TREATMENTS & $\begin{array}{c}\text { VERTICAL } \\
\text { AXIS (V) }\end{array}$ & $\begin{array}{c}\text { HORIZONTAL } \\
\text { AXIS (H) }\end{array}$ & $\begin{array}{c}\text { AIR BLOW } \\
\text { RATE(A) }\end{array}$ & $\begin{array}{c}\text { DECK OSCILLATION } \\
\text { SPEED (D) }\end{array}$ \\
\hline $\mathbf{T}_{\mathbf{1}}$ & 0.5 & 0.5 & 3 & 400 \\
\hline $\mathbf{T}_{\mathbf{2}}$ & 0.5 & 1 & 3.5 & 400 \\
\hline $\mathbf{T}_{\mathbf{3}}$ & 0.5 & 1 & 3.5 & 450 \\
\hline $\mathbf{T}_{\mathbf{4}}$ & 0.5 & 1 & 3.5 & 465 \\
\hline $\mathbf{T}_{\mathbf{5}}$ & $\mathbf{0 . 5}$ & $\mathbf{1 . 5}$ & $\mathbf{3}$ & $\mathbf{4 5 0}$ \\
\hline $\mathbf{T}_{\mathbf{6}}$ & 0.5 & 1.5 & 3 & 500 \\
\hline $\mathbf{T}_{\mathbf{7}}$ & 0.5 & 1.5 & 3.5 & 500 \\
\hline $\mathbf{T}_{\mathbf{8}}$ & 1 & 0.5 & 3 & 450 \\
\hline $\mathbf{T}_{\mathbf{9}}$ & 1 & 0.5 & 3 & 465 \\
\hline $\mathbf{T}_{\mathbf{1 0}}$ & 1 & 0.5 & 3 & 500 \\
\hline $\mathbf{T}_{\mathbf{1 1}}$ & 1 & 1 & 3 & 400 \\
\hline $\mathbf{T 1}_{\mathbf{1 2}}$ & 1 & 1 & 3 & 465 \\
\hline $\mathbf{T}_{\mathbf{1 3}}$ & 1 & 1.5 & 3 & 450 \\
\hline $\mathbf{T}_{\mathbf{1 4}}$ & 1.5 & 0.5 & 3 & 500 \\
\hline $\mathbf{T}_{\mathbf{1 5}}$ & 1.5 & 1 & 3 & 450 \\
\hline $\mathbf{T}_{\mathbf{1 6}}$ & 1.5 & 1.5 & 3 & 450 \\
\hline $\mathbf{T}_{\mathbf{1 7}}$ & 1.5 & 1.5 & 3 & 465 \\
\hline
\end{tabular}


Table.2 Seed recovery percent and 1000 seed weight of the graded Amaranthus seed

\begin{tabular}{|c|c|c|c|c|c|c|c|c|c|c|}
\hline \multirow{2}{*}{$\begin{array}{l}\text { TREATMENT/ } \\
\text { GRADE }\end{array}$} & \multicolumn{5}{|c|}{ SEED RECOVERY (\%) } & \multicolumn{5}{|c|}{1000 SEED WEIGHT(mg) } \\
\hline & A & B & $\mathrm{C}$ & D & $\mathrm{E}$ & A & B & $\mathrm{C}$ & D & $\mathrm{E}$ \\
\hline $\mathbf{T}_{1}$ & 43.98 & 37.46 & 17.56 & 0.86 & 0.05 & 67.25 & 63.00 & 59.62 & 53.50 & 48.6 \\
\hline $\mathbf{T}_{2}$ & 1.84 & 8.80 & 16.30 & 33.00 & 40.50 & 73.00 & 68.00 & 67.00 & 67.00 & 55.00 \\
\hline $\mathbf{T}_{3}$ & 13.40 & 17.40 & 20.70 & 22.90 & 25.90 & 74.00 & 71.00 & 69.00 & 68.00 & 60.00 \\
\hline $\mathbf{T}_{4}$ & 72.50 & 22.40 & 3.32 & 1.18 & 0.47 & 66.00 & 63.00 & 54.00 & 46.00 & 42.00 \\
\hline T5 & 54.00 & 31.92 & 12.93 & 1.05 & 0.46 & 73.50 & 60.75 & 57.65 & 56.37 & $\mathbf{5 0 . 5 0}$ \\
\hline $\mathbf{T}_{6}$ & 79.46 & 14.91 & 4.64 & 0.61 & 0.36 & 67.62 & 59.00 & 56.50 & 55.12 & 54.33 \\
\hline $\mathbf{T}_{7}$ & 71.42 & 21.90 & 5.60 & 0.73 & 0.12 & 67.25 & 65.37 & 58.25 & 54.50 & 48.00 \\
\hline $\mathbf{T}_{8}$ & 89.90 & 9.21 & 0.54 & 0.27 & - & 68.00 & 54.00 & 46.00 & 35.00 & - \\
\hline $\mathbf{T}_{9}$ & 49.00 & 35.00 & 15.00 & 0.90 & 0.10 & 73.12 & 67.75 & 66.62 & 54.25 & 52.17 \\
\hline$T_{10}$ & 98.90 & 1.06 & - & - & - & 51.00 & 44.00 & 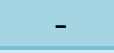 & 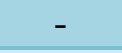 & - \\
\hline $\mathbf{T}_{11}$ & 2.00 & 9.46 & 22.90 & 23.20 & 43.30 & 76.00 & 69.00 & 68.00 & 61.00 & 56.00 \\
\hline T12 & 38.40 & 20.60 & 19.34 & 13.50 & 8.04 & 72.00 & 67.00 & 64.00 & 62.00 & 57.00 \\
\hline $\mathbf{T}_{13}$ & 76.60 & 21.90 & 1.04 & 0.39 & 0.01 & 73.00 & 63.00 & 56.00 & 46.00 & 44.00 \\
\hline$T_{14}$ & 35.12 & 33.05 & 28.82 & 2.58 & 0.41 & 72.75 & 67.62 & 61.00 & 55.00 & 52.62 \\
\hline $\mathbf{T}_{15}$ & 40.90 & 17.97 & 15.67 & 12.60 & 11.30 & 75.00 & 72.00 & 66.00 & 60.00 & 49.00 \\
\hline $\mathbf{T}_{16}$ & 30.70 & 26.30 & $20 . .67$ & 13.92 & 8.92 & 77.00 & 76.00 & 66.00 & 58.00 & 56.00 \\
\hline $\mathbf{T}_{17}$ & 35.14 & 26.02 & 17.50 & 13.08 & 8.23 & 70.00 & 69.00 & 67.00 & 63.00 & 61.00 \\
\hline BULK & & & & & & & & 65.08 & & \\
\hline
\end{tabular}

Table.3 Seed quality parameters after grading of Amaranthus seeds in specific gravity separators

\begin{tabular}{|c|c|c|c|c|c|c|}
\hline & $\begin{array}{c}\text { Germination } \\
(\mathbf{\%})\end{array}$ & $\begin{array}{c}\text { Shoot length } \\
(\mathbf{c m})\end{array}$ & $\begin{array}{c}\text { Root length } \\
(\mathbf{c m})\end{array}$ & $\begin{array}{c}\text { Dry matter } \\
(\mathbf{m g} / \mathbf{1 0} \text { seedling) }\end{array}$ & $\begin{array}{c}\text { Vigour } \\
\text { Index I }\end{array}$ & $\begin{array}{c}\text { Vigour } \\
\text { Index II }\end{array}$ \\
\hline Bulk & $\begin{array}{c}72 \\
(56.790)\end{array}$ & 2.32 & 4.19 & 4.33 & 469 & 3.11 \\
\hline $\mathrm{T} 1$ & $\begin{array}{c}75 \\
(60.001)\end{array}$ & 2.42 & 4.51 & 5.66 & 518 & 4.23 \\
\hline $\mathrm{T}_{4}$ & $\begin{array}{c}83 \\
(65.651)\end{array}$ & 3.14 & 5.27 & 6.33 & 701 & 5.28 \\
\hline $\mathrm{T}_{5}$ & $\begin{array}{c}72 \\
(58.053)\end{array}$ & 2.84 & 4.46 & 6.0 & 525 & 4.30 \\
\hline $\mathrm{T}_{6}$ & $\begin{array}{c}80 \\
(63.436)\end{array}$ & 3.01 & 4.48 & 6.66 & 598 & 5.33 \\
\hline $\mathrm{T}_{7}$ & $\begin{array}{c}73 \\
(58.053)\end{array}$ & 2.45 & 5.04 & 4.5 & 549 & 3.30 \\
\hline $\mathrm{T}_{9}$ & $\begin{array}{c}72 \\
(58.053)\end{array}$ & 2.90 & 5.17 & 5.33 & 582 & 3.84 \\
\hline $\mathrm{T}_{13}$ & $\begin{array}{c}77 \\
(61.343)\end{array}$ & 2.79 & 5.02 & 5.33 & 597 & 4.08 \\
\hline $\mathrm{S} . \mathrm{ED}$ & 1.9437 & 0.1880 & 0.4795 & 0.6922 & 41.4528 & 0.8456 \\
\hline $\mathrm{CD}$ & 4.1204 & 0.3985 & 1.0165 & 1.4675 & 87.8771 & 1.7926 \\
\hline
\end{tabular}


The maximum shoot length $(3.14 \mathrm{~cm})$ obtained from $\mathrm{T}_{4}(\mathrm{~V}-0.5, \mathrm{H}-1, \mathrm{~A}-3.5$, D- 465) followed by $\mathrm{T}_{6}(\mathrm{~V}-0.5, \mathrm{H}-1.5$, A- 3,D- 500) of $3.01 \mathrm{~cm}$. The minimum shoot length $(2.32$ $\mathrm{cm}$ ) obtained from the control followed by $\mathrm{T}_{1}(\mathrm{~V}-0.5, \mathrm{H}-1.5, \mathrm{~A}-3.5, \mathrm{D}-500)$ of $2.42 \mathrm{~cm}$. The similar results were obtained from the results of Menaka and Balamurugan (2008) in Amaranthus and Manikandan and Srimathi (2014) in Amaranthus. The maximum root length $(5.27 \mathrm{~cm})$ was obtained from treatment $\mathrm{T}_{4}(\mathrm{~V}-0.5, \mathrm{H}-1.5, \mathrm{~A}-3, \mathrm{D}-450 \mathrm{rpm})$ and followed by $5.17 \mathrm{~cm}$ from $\mathrm{T}_{9}(\mathrm{~V}-1, \mathrm{H}-0.5$, A -3, D- $465 \mathrm{rpm})$. The minimum root length was obtained from control $(4.19 \mathrm{~cm})$ followed by the treatment $\mathrm{T}_{5}(4.46 \mathrm{~cm})$. The results obtained from the results of Manikandan and Srimathi (2014) were similar. The larger shoot length and root length was due to the larger size of the seeds. The larger seeds usually larger sized seedlings both shoot and root length.

The maximum dry matter was obtained from the treatment $\mathrm{T}_{6}(6.6 \mathrm{mg} / 10$ seedlings $)$ and followed by $\mathrm{T}_{4}(6.3 \mathrm{mg} / 10$ seedlings $)$ and the minimum dry matter was obtained from the control $(4.33 \mathrm{mg} / 10$ seedlings) followed by treatment $\mathrm{T}_{7}(4.5 \mathrm{mg} / 10$ seedlings $)$. The highest dry matter in $T_{6}$ and $T_{4}$ because of the fact that the seeds with large seeds have more food reserve material and more number of cells per cotyledon may increase the dry matter accumulation and thus increase the dry weight of the seedlings (Guldan and Brun, 1985). Vishwanath et al., (2019) in soybean concluded that the seeds with larger size will have larger dry matter accumulation than the seeds with smaller size. Chandraprakash et al., (2019) in caster agree with the similar results.

The maximum vigour index I obtained from the treatment $\mathrm{T}_{4}$ (701) followed by $\mathrm{T}_{6}(598)$ and the minimum treatment was obtained from the bulk (469) followed by treatment $T_{1}$
(518). The maximum vigour index II was obtained from the treatment $\mathrm{T}_{6} \quad(5.33)$ followed by the treatment $\mathrm{T}_{4}$ (5.28) and the minimum was obtained from the bulk (3.11) which is followed by treatment $\mathrm{T}_{7}$ (3.30) (Table 3). The size of the seeds might directly influence the vigour of the seedlings. This was described as large sized seeds have the mature embryo with containing more food reserves and nutrients which provides physiological stamina for the seeds (Pollock and Roos, 1972). Yogeesha (2013) in okra and Menaka and Balamurugan (2008) in Amaranthus reported the similar results of heavier the seed weight with highest vigour index.

From the above data results it is clear that the germination and other seed quality parameters were good in grade A whereas the grade with only large sized seeds with high weight due to absence of ill filled seeds and presence of fully developed embryo and of food reserves that completely utilized during germination that its utilization of nutrients and stamina was expressed on vigour of the seedling. The positive correlation between weight of the seeds and its germination was similar to Anon (1996) in sunflower and soybean, Patil and Sarode (1998) in wheat and Saraswathi (1995) in cotton. Similar records were observed in Dharmalingam (1989) and Anon (1998) in Eucalyptus of having highest germination and other quality characters which are influenced by its weight and its srorage food reserves.

It is concluded, thus the seeds of Amaranthus polygonoides var. PLR 1 could be graded with the machine setting of $0.5 \mathrm{~cm}$ of vertical height, $1.5 \mathrm{~cm}$ of horizontal height, $3.5 \mathrm{~m}^{3} / \mathrm{hr}$ of air flow rate and $465 \mathrm{rpm}$ of deck oscillation speed for obtaining heavier seeds with maximum seed recovery of $92 \%$ (grade A + grade B) and highest germination (83\%) and vigour (701). 


\section{References}

Abdul -Baki, A.A and Baker. 1973. Changes in cellular organelles for membranes related to vigour loss in seed. Seed science and Technology. 1: 89-125.

Abdul -Baki, AA. Anderson J.D. 1973 Vigour determination in soybean seed by multiple criteria. Crop Sci.13:630632.

Annonymous. 1996. Research Highlights. National Seed Project.

Balamurugan P. 1993. Seed production techniques in BSH 1 and quality assessment in parental lines and hybrid sunflower (Helianthus annuus L.). Ph.D Thesis, Tamil Nadu Agricultural University, Coimbatore.

Chandraprakash. P., Masilamani P., Rajkumar P., Geetha R., Alex Albert.V and Eevera, T. 2019. Effect of specific gravity separation on seed germination and biochemical potential of Castor hybrid YRCH. Journal of Pharmacognasy and Phytochemistry., 8(4): 2269-2273.

Dharmalingam, C., Daniel, S.D., Ramakrishnan V., Karivaratharaju, T.V., and Thangaraj, M. 1973. Influence of seed separation and upgrading on germination in Eukalyptus hybrid seeds. Madras Agric J. 1973., 60: 1714- 1718.

Gowda, B., and Gowda, S.J., 1996. Seed quality of hybrid sorghum as influenced by gravity separation. Crop Res., 12, 395-397.

Guldan, S.J. and Brun, W.A. 1985. Relationship of cotyledon cell number and seed respiration to soybean seed growth. Crop Science. 25: 85-92.

ISTA, 1999. International Rules for Seed Testing. Seed Science and Technology 27: 27-32.

Manikandan. S and Srimathi. P. 2014, Studies on post-harvest seed handling techniques on grain amaranth (Amaranthus hypochondriacus L.) cv. Suvarna., Current Biotica, 8(2): 132141.

McDaniel R.G. 1969. Relationship of seed weight, seedling vihour and mitochondrial metabolism in barely, Crop science. 9: 223-827.

Menaka . C and Balamurugan, 2008. Seed grading techniques in Amaranthus cv. Co-5. Plant Arch., 8: 729-731.

Nagi H.C.S., Kant. K and Verma, M.M.1988. Improving germination by grading in soybean. Seeds and Farms., 14(7): 1719.

Panse VG, Sukhatme RV, Statistical methods for Agricultural workers.1999. Indian council of Agricultural Research Publications New Delhi.

Patil, V.N and Sarode, S.D. 1998. Seed quality in wheat as influenced by specific gravity separation. Seed Research., 16(1): 114- 116.

Pollock, B.M. and Roos, E.E. 1972. Seed and Seedling Vigour. In: Seed Biology I, Kozlowaski, T.T. (Ed.). Academic Press, New York, USA pp: 313-387.

Saraswathi, G. 1995. Studies on seed pelleting in relation to sowing qualities of cotton cv. LRA 5166 Gossypium hirsutum L. M.sc (Ag) Thesis, Tamil Nadu Agricultural University, Coimbatore.

Umarani, R and Vanangamudi, K. 2002. The effect of Specific gravity separation on germination and biochemical potential of Casuarina equistifolia seeds. J.Trop. For. Sci; 14:207-212.

Umarani, R. 1999. Studies on the phyiological and biochemical basis of seed germination and deterioration in Casuarina equisetifolia. Ph.d (Ag) Thesis. Tamil Nadu Agricultural University, Coimbatore.

Vishwanath, Ravi Hunje, Gurumurthy, R. and Manjunatha, M.V. 2019. Influence of 
Specific Gravity Separator on Seed Quality Parameters of Soybean var. $\mathrm{DSb}$ - 21. International Journal of Current Microbiology Applied Sciences; 8(1) 1707- 1713.
Yogeesha, H.S, Kashinath, B.L, Bhanupriya, K. Naik, L.B. Seed quality improvement in okra through specific gravity separation. Hortyl. Sci. 2013; 8: 70-73.

\section{How to cite this article:}

Kavinila, R., R. Geetha, R. Chandraprakash and Sujatha, K. 2020. Seed Quality Improvement in Amaranthus polygonoides var. PLR 1 through Specific Gravity Separator. Int.J.Curr.Microbiol.App.Sci. 9(10): 635-641. doi: https://doi.org/10.20546/ijcmas.2020.910.075 